\title{
MARKET BASKET ANALISYS DATA MINING TERHADAP DATA PENJUALAN MENGGUNAKAN ALGORITMA FREQUENT PATTERN GROWTH (FP GROWTH)
}

\author{
Numan Musyaffa[1]; Arfhan Prasetyo[2]; Ricki Sastra[3] \\ Program Studi Sistem Informasi[1],Program Studi Teknik Informatika[2], Program Studi Teknologi \\ Komputer ${ }^{[3]}$ \\ Universitas Nusa Mandiri[1][2]Universitas Bina Sarana Informatika ${ }^{[3]}$ \\ Numan.nmf@nusamandiri.ac.id[1], arfhan.afp@nusamandiri.ac.id ${ }^{[2], R i c k i . r k t @ b s i . a c . i d ~}{ }^{[3]}$
}

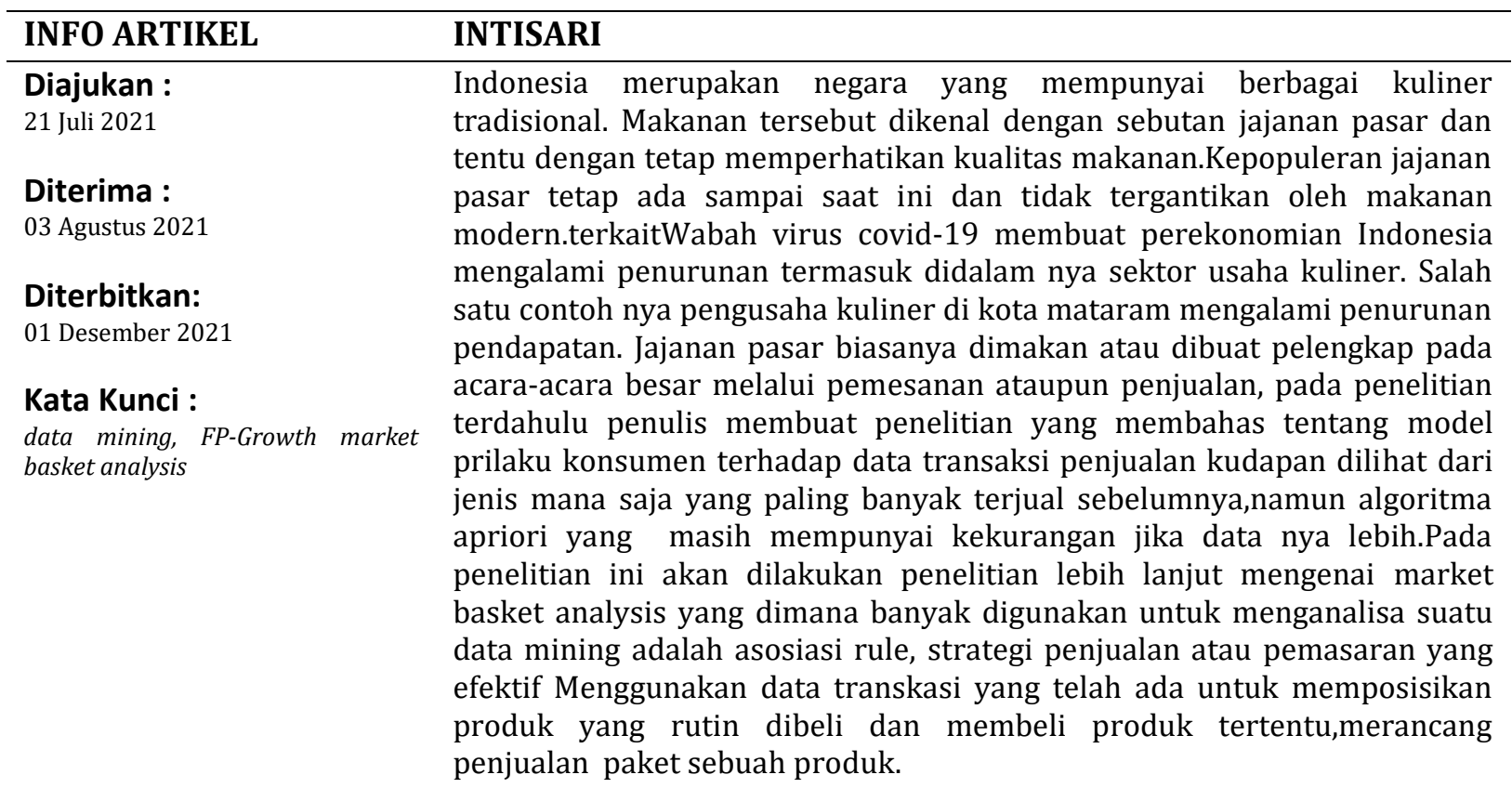

\section{PENDAHULUAN}

Indonesia memiliki aneka kuliner tradisonal yang dikenal dengan jajanan pasar. Jajanan tradisional ini menjadi salah satu jajanan yang tergolong menyehatkan. Meski jajanan moderan semakin banyak jajanan pasar masih tetap ada(Guide, 2018). namun belakangan ini dampak dari aturan Pembatasan Kegiatan Masyarakat yang di keluarkan oleh Pemerintahan terkait Dampak virus covid-19 membuat menurunnya perekonomian bangsa, termasuk didalam nya sektor usaha makanan. Seperti pengusaha kuliner di kota matraman ikut terdampak yang berakibat menurunnya pendapatan.Selain itu penetapan PPKM juga membuat konsumen hanya bisa memesan secara online.

Jajanan pasar biasanya dimakan atau dibuat pelengkap pada acara-acara besar melalui pemesanan ataupun penjualan, pada penelitian terdahulu penulis membuat penelitian yang membahas tentang pola kebiasaan konsumen melalui data Transaksi sebelum nya yang terjadi dengan melihat jenis kuliner apa saja yang paling diminati konsumen. Mendata kuliner atau jajanan pasar apa saja yang ikut dibeli bersamaan yang diambil dari usaha rumahan Dapoerin's.(Prasetyo, Musyaffa, \& Sastra, 2020).

Pada penelitian diatas menggunakan data mining asosiasi rule dengan algoritma apriori masih terdapat kekurangan jika datanya lebih hal ini yang mendasari dilakukan penelitian lebih lanjut mengenai market basket analysis menggunakan algoritma FP Growth yang lebih sering digunakan menganalisa data mining adalah asosiasi rule(nurelasari,2017).Analisis penjualan berfungsi untuk membuat metode yang baru berkaitan penjualan atau pemasaran dengan menggunakan data transaksi yang ada.Menganalisa produk apa saja yang banyak dibeli(Firman,2019). Implementasi algoritma FP Grwoth digunakan sebagai analisis prilaku pembeli dengan menganalisis penjualanan terlaris dan keterkaitan antara dua item atau lebih yang nantinya akan berdampak pada transaksi(Fitria,Nengsih,\& Qudsi, 2017). 


\section{BAHAN DAN METODE}

Data mining adalah ilmu yang menjelaskan hasil penemuan berupa pengetahuan terhadap sekumpulan data,proses data mining menggunakan teknik statistic matematik, kecerdasan buatan dan mesin pemelajaran untuk mengekstraski dan identifikasi informasi (kanti \& Indrajit, 2017).Market Basket analysis merupakan metode yang tepat untuk lingkungan marketing. Tujuan dari Market Basket analysis untuk menentukan produk apa saja yang dibeli konsumen secara bersamaan diwaktu sama. Metode ini sendri namanya berasal dari prilaku pembeli memasukan barang ke keranjang (kusbianto PA,Ananta, \& Nanda,2019).

Algoritma FP Growth adalah pengembangan dari algoritma Apriori,merupakan salah satu alternative yang digunakan dalam menentukan himpunan data yang sering kali tampil di kumpulan data (lestari,2017).

Bentuk umum dari Association rules yaitu:

A1...., An $\rightarrow$ B

Yang artinya bahwa konsumen yang membeli produk A juga berpeluang untuk membeli produk B (Kusbianto PA et al., 2019).

\section{Pembentukan Aturan Asosiatif}

Ketika setiap frekuensi paling tinggi didapatkan, kemudian dicari aturan asosiatif dengan syarat minimum untuk confidence melalui perhitungan confidence.

$$
\begin{aligned}
& \text { Confidence }=\boldsymbol{P}\left(\frac{B}{A}\right) \\
& \frac{=\sum \text { Transaksi Mengandung A dan B }}{\sum \text { Transaksi Mengandung A }}
\end{aligned}
$$

\section{Rapid Miner}

Penulis menggunakan Software pengujian data mining rapidminer untuk melihat seberapa akurasinya data transaksi penjualan yang dimasukan dengan melihat hasil pola kombinasi yang dihasilkan oleh aturan asosiasi serta kesesuaiannya dengan algoritma FP- Growth yang akan di uji oleh penulis.

\section{HASIL DAN PEMBAHASAN}

\section{Tahap pembangkitan conditional pattern}

Pada tahap ini penulis mengumpulkan data dari penelitiian sebelumnya yang penulis lakukan yaitu jajanan pasar yang diproduksi rumahan Dapoerin's dengan daftar produk jajanan pasar sebagai berikut :

Tabel 1. List Produk

\begin{tabular}{|c|c|}
\hline No & Nama Produk \\
\hline 1 & Lontong \\
\hline 2 & KueLumpur \\
\hline 3 & Risol \\
\hline 4 & Kue Putu Ayu \\
\hline 5 & Kue Pastel \\
\hline 6 & Bolu \\
\hline 7 & Donat bulat \\
\hline 8 & Pisang coklat \\
\hline 9 & Tahu goreng \\
\hline 10 & Tahu bakso \\
\hline 11 & Molen \\
\hline 12 & Kue pandan \\
\hline 13 & Kue pisang \\
\hline
\end{tabular}

Sumber : Hasil Penelitian (2021)

Kemudian peneliti mengelompokkan 3 produk yang paling banyak terjual berdasarkan pada data penjualan selama satu bulan dan didapat model transaksi dengan menganalisa produk yang paling laris terjual baik secara pemesanan maupun terjual secara bukan hasil pesanan acara, berikut produk yang terjual selama 1 bulan :

Tabel 2. Tiga roduk jajanan pasar yang paling banyak dibeli

\begin{tabular}{|l|l|}
\hline $\begin{array}{l}\text { Tanggal } \\
\text { Transaksi }\end{array}$ & Itemset \\
\hline \hline 08 & Lontong, kue PutuAyu, Risol \\
\hline 10 & Lontong, kue PutuAyu, Pastel \\
\hline 11 & Lontong, Risol, Pisang coklat \\
\hline 12 & Lontong, Pisang coklat, Risol \\
\hline 13 & $\begin{array}{l}\text { Kue PutuAyu, Lontong, Tahu } \\
\text { goreng }\end{array}$ \\
\hline 14 & Lontong, Pisang coklat, Bolu \\
\hline 15 & Pastel, kue Putu Ayu, Pisang coklat \\
\hline 20 & Lontong, molen, kue PutuAyu \\
\hline 21 & $\begin{array}{l}\text { Kue PutuAyu, Lontong, Pisang } \\
\text { coklat }\end{array}$ \\
\hline 22 & Lontong, Risol, Pisang coklat \\
\hline 23 & Kue PutuAyu, Pastel, Lontong \\
\hline 24 & $\begin{array}{l}\text { Kue PutuAyu, Kue Lumpur, } \\
\text { Lontong }\end{array}$ \\
\hline 25 & Bolu, Lontong, Risol \\
\hline 26 & Pastel, Lontong, Kue Lumpur \\
\hline
\end{tabular}

Sumber : Hasil Penelitian (2021) 
Selanjutnya penulis membuat table tabular, untuk memudahkan pencarian data itemset mana saja pada data hasil penjualan pada tabel 2 yang sering muncul atau sering dijual setiap hari nya, dan data tabularnya berikut ini:

Tabel 3.Data transaksi bentuk Tabular

\begin{tabular}{|c|c|c|c|c|c|c|c|c|c|}
\hline $\begin{array}{c}\mathrm{Tg} \\
\mathrm{l}\end{array}$ & $\begin{array}{l}\text { Lo } \\
\text { nt } \\
\text { o } \\
\text { ng }\end{array}$ & $\begin{array}{l}\text { Kue } \\
\text { putu } \\
\text { ayu }\end{array}$ & Risol & $\begin{array}{l}\text { Kue } \\
\text { Pas } \\
\text { tel }\end{array}$ & $\begin{array}{l}\text { Pisan } \\
\text { g } \\
\text { coklat }\end{array}$ & $\begin{array}{l}\text { Ta } \\
\text { hu } \\
\text { gor } \\
\text { en } \\
\text { g }\end{array}$ & Bol u & $\begin{array}{l}\text { mol } \\
\text { en }\end{array}$ & $\begin{array}{l}\text { Kue } \\
\text { Lum } \\
\text { pur }\end{array}$ \\
\hline 8 & 1 & 1 & 1 & 0 & 0 & 0 & 0 & 0 & 0 \\
\hline 10 & 1 & 1 & 0 & 1 & 0 & 0 & 0 & 0 & 0 \\
\hline 11 & 1 & 0 & 1 & 0 & 1 & 0 & 0 & 0 & 0 \\
\hline 12 & 1 & 0 & 1 & 0 & 1 & 0 & 0 & 0 & 0 \\
\hline 13 & 1 & 1 & 0 & 0 & 0 & 1 & 0 & 0 & 0 \\
\hline 14 & 1 & 0 & 0 & 0 & 1 & 0 & 1 & 0 & 0 \\
\hline 15 & 0 & 1 & 0 & 1 & 1 & 0 & 0 & 0 & 0 \\
\hline 20 & 1 & 1 & 0 & 0 & 0 & 0 & 0 & 1 & 0 \\
\hline 21 & 1 & 1 & 0 & 0 & 1 & 0 & 0 & 0 & 0 \\
\hline 22 & 1 & 0 & 1 & 0 & 1 & 0 & 0 & 0 & 0 \\
\hline 23 & 1 & 1 & 0 & 1 & 0 & 0 & 0 & 0 & 0 \\
\hline 24 & 1 & 1 & 0 & 0 & 0 & 0 & 0 & 0 & 1 \\
\hline 25 & 1 & 0 & 1 & 0 & 0 & 0 & 1 & 0 & 0 \\
\hline 26 & 1 & 0 & 0 & 1 & 0 & 0 & 0 & 0 & 1 \\
\hline
\end{tabular}

Sumber : Hasil Penelitian (2021)

Dari data tabular pada tabel 3 di lakukan pengurutan item yang memiliki frekuensi terbanyak dalam setiap penjualan produk jajanan pasar setiap harinya, berikut hasilnya dapat dilihat pada tabel 4

Tabel 4. Kemunculan Item diurut berdasarkan frekuensi tertinggi

\begin{tabular}{|c|c|}
\hline Item & Frekuensi \\
\hline Lontong & 13 \\
\hline Kue Putu Ayu & 8 \\
\hline Kue pisang coklat & 6 \\
\hline Risol & 5 \\
\hline Pastel & 4 \\
\hline Tahu Isi & 2 \\
\hline Bolu & 2 \\
\hline molen & 2 \\
\hline Kue Lumpur & 2 \\
\hline
\end{tabular}

Sumber : Hasil Penelitian (2021)

Untuk memudahkan dalam praproses pengolahan data pada FP Growth penulis membuat kode produk jajajan pasar dari tabel 4 diatas, seperti berikut ini :

Tabel 5. Kode Produk Jajanan Pasar

\begin{tabular}{|c|c|}
\hline Itemset & Kode Produk \\
\hline Lontong & LT \\
\hline Putu Ayu & PA \\
\hline
\end{tabular}

\begin{tabular}{|c|c|}
\hline Pisang coklat & PC \\
\hline Risol & RS \\
\hline Pastel & PL \\
\hline Tahu Isi & TI \\
\hline Bolu & BM \\
\hline Molen & OD \\
\hline Kue Lumpur & KL \\
\hline
\end{tabular}

Sumber : Hasil Penelitian (2021)

Setelah dilakukan pengurutan item pada tabel 4 maka yang memiliki frekuensi diatas support count $\geq 4$ adalah LT, PA, PK, RS, PL. dari 5 item tersebut yang akan berpengaruh dan akan dimasukan ke dalam FP-Tree, selebihnya (TI, BM, OD, dan KL) dapat dihilangkan karena tidak berpengaruh signifikan sehingga menghasilkan item yang memenuhi support count sebagai berikut :

Tabel 6. Item yang memenuhi support count

\begin{tabular}{|c|c|}
\hline Item & Jumlah \\
\hline LT & 13 \\
\hline PA & 8 \\
\hline PK & 6 \\
\hline RS & 5 \\
\hline PL & 4 \\
\hline
\end{tabular}

Sumber :Hasil Penelitian (2021)

\section{Pembangkitan Frequent Pattern Tree (FP TREE)}

Setelah terbentuknya item yang memenuhi Support count yang dapat dilihat pada tabel 6, maka tahap selanjutnaya adalah pembentukan FP Tree, berikut ini adalah tabel dataset item berdasarkan prioritas yang sudah terbentuk berdasarkan hasil transaksi setiap harinya selama 1 bulan :

Tabel 7. Data Item Transaksi Yang Sering Muncul Dalam 1 Bulan

\begin{tabular}{|c|c|}
\hline Tanggal & Items Transaksi \\
\hline 8 & LT, PA, RS \\
\hline 10 & LT, PA, PL \\
\hline 11 & LT, PK, RS \\
\hline 12 & LT, PK, RS \\
\hline 13 & LT, PA \\
\hline 14 & LT, PK \\
\hline 15 & PA, PK, PL \\
\hline
\end{tabular}




\begin{tabular}{|c|c|}
\hline 20 & LT, PA \\
\hline 21 & LT, PA, PK \\
\hline 22 & LT, PK, RS \\
\hline 23 & LT, PA, PL \\
\hline 24 & LT, PA \\
\hline 25 & LT, RS \\
\hline 26 & LT, PL \\
\hline
\end{tabular}

Sumber : Hasil Penelitian (2021)

Selanjutnya pembentukan FP tree berdasarkan Tabel 7 diatas yang diurutkan berdasarkan support count, Setiap simpul pada Fp-Tree mengandung nama sebuah produk dan counter support menghitung frekuensi kemunculan produk dalam tiap lintasan. Kumpulan data dicek pertama kali untuk menentukan support count dari setiap produk,yang tidak memenuhi frequent akan dihilangkan, sedangkan yang memenuhi frequent dimasukkan dan disusun dengan urutan dari atas ke bawah.

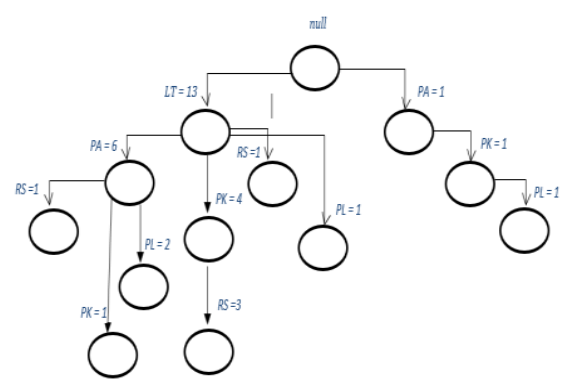

Sumber: Hasil Penelitian (2021)

Gambar1. FP Tree Data Transaksi 1 bulan

\section{Aturan Asosiasi FP-Growth}

Langkah berikutnya Rule Asosiasi Algoritma Fp-Growth digunakan untuk menemukan semua frequent itemset yang berakhiran JAC, JEEW, JB, dan JCE setelahnya dilakukan pengecekkan support count memenuhi minimum support count7. Dari pembangkitan Fp-Tree yang telah dilakukan maka didapat hasil conditional pattern base seperti berikut :

Tabel 8. Hasil Conditional Pattern Base

\begin{tabular}{|c|c|c|}
\hline Item & $\begin{array}{c}\text { Conditional } \\
\text { Pattern Base }\end{array}$ & $\begin{array}{c}\text { Frequent Pattern } \\
\text { Base }\end{array}$ \\
\hline \multirow{2}{*}{ PL } & $\{\mathrm{LT}, \mathrm{PA}: 2\}$, & $<\mathrm{LT}: 3, \mathrm{PA}: 3>$ \\
& $\{\mathrm{LT}: 1\},\{\mathrm{PA}, \mathrm{PK}:$ & $<\mathrm{PK}: 1>$ \\
& $3\}$ & \\
\hline $\mathrm{RS}$ & $\{\mathrm{LT}, \mathrm{PA}: 1\}$, & $<\mathrm{LT}: 5, \mathrm{PA}: 1>$, \\
& $\{\mathrm{LT}: 1\},\{\mathrm{LT}$, & $<\mathrm{PK}: 3>$ \\
\hline
\end{tabular}

\begin{tabular}{|c|c|c|}
\hline & PK:3 $\}$ & \\
\hline PK & $\begin{array}{c}\{\text { LT, PA:1\}, } \\
\{\text { LT:4\}, }\{\text { PA:1 }\}\end{array}$ & $<$ LT:5, PA:2> \\
\hline PA & $\{$ LT:7\}, & $<$ LT:7> \\
\hline LT & - & - \\
\hline
\end{tabular}

\section{Pengujian Menggunakan RapidMiner}

penulis melakukan pengujian menggunakan software data mining yaitu Rapidminer, berikut Langkah-langkah pembentukan model mining menggunakan algoritma Fpgrowth dan aturan asosisasi :

1. Pembuatan dataset format tabular menggunakan MS.Excel seperti gambar dibawah ini :

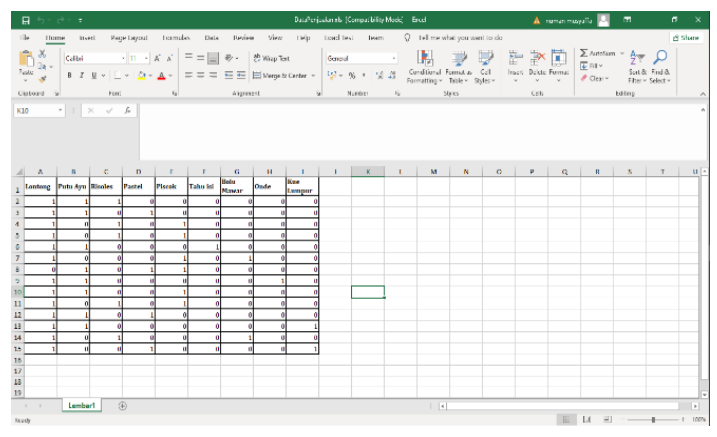

GamGambar 2. Format Tabular Data Penjualan

2. Lalu jalankan software Rapid Miner, kemudian read excel import data tabular dari excel kedalam Rapid Miner dari data inilah yang nantinya akan membentuk kandidat itemset dan aturan asosiasi sebagai berikut :

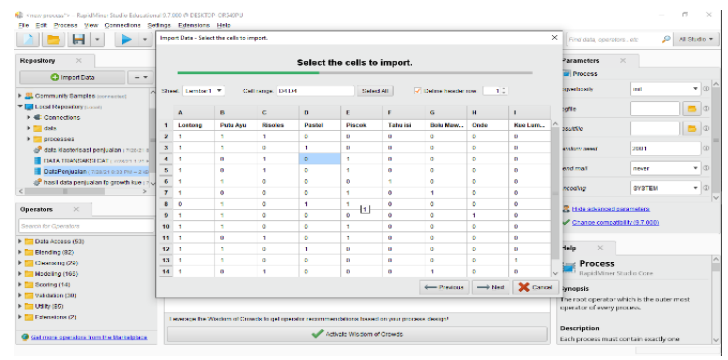

Gambar 3. Tampilan data exampleset transaksi penjualan

3. Kemudian di bagian design memasukkan file excel yang sudah di import pada repository sebagai database, memulai pengolahan data pada rapid miner memerlukan 4 operator, operator ini yang nantinya akan memproses 
data secara bertahap, mulai dari select attributes, numerical to binominal, fp-growth dan create association rule. Selanjutnya untuk menentukan minimum support pada operator fp-growth dengan nilai desimal 0,30 dan minimum confidence pada create assosciation rule dengan nilai desimal 0,6.

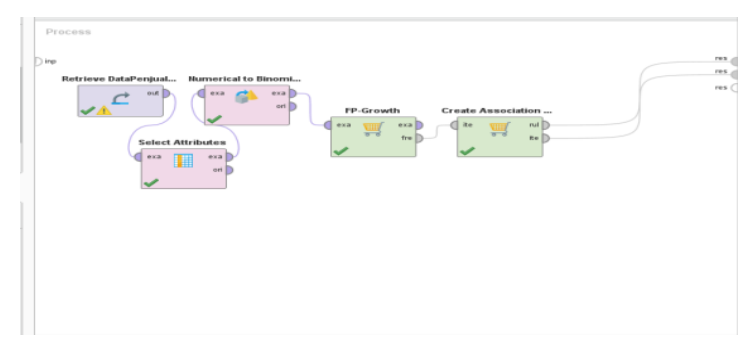

Gambar 4. Tahapan pengujian Fp-groth dengan rapidminer

4. Hasil dari proses klik start untuk pengolahan data yang sudah kita design terdapat 2 table yaitu tabel pertama untuk menampilkan kandidat itemset sedangkan tabel kedua untuk aturan asosiasi. Table pertama setelah dilakukan pencocokan data berdasarkan perhitungan manual yang telah memenuhi syarat minimum, maka data yang memenuhi support 30\% diberi tanda warna biru pada pengolahan aplikasi rapidminer dan selebihnya data tanpa warna tidak memenuhi minimum support.

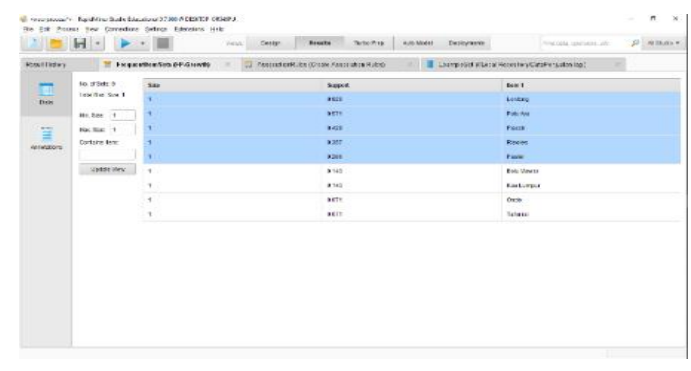

Gambar 5. Frequent Itemset (FP Growth) 1 Item set

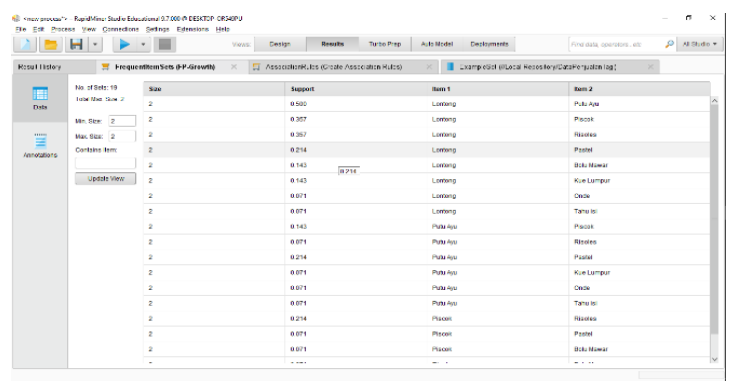

Gambar 6. Frequent Itemset (FP Growth)

\section{Item set}

Selanjutnya pencocokan data table kedua berdasarkan perhitungan manual yang telah memenuhi syarat minimum confidence, maka data yang memenuhi confidence $60 \%$ seperti pada gambar 6 diatas.

5. Hasil pengujian aturan asosiasi fp growth dengan rapidminer yang dihasilkan dari kedua algoritma diketahui bahwa hasil perhitungan rule yaitu seperti gambar dibawah ini :

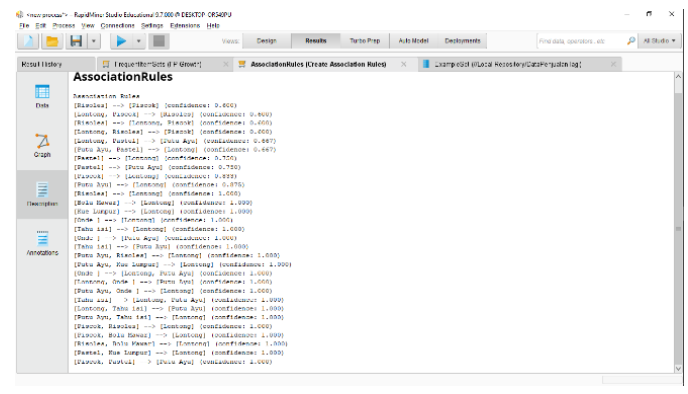

Gambar 7. Rules yang dihasilkan

Dari hasil pengujian dan Analisa yang dilakukan dapat ditarik kesimpulan bahwa data mining dengan algoritma FP Growth dapat diimplementasi dengan data penjualan kuliner olahan rumahan Dapoerin's.kemudian metode asosiasi rule dengan menggunakan algoritma FP growth dengan parameter support dan confidence dapat membentuk korelasi barang pembelian untuk lebih meningkatkan pemesanan dan penjualan. Setelah dilakukan pengujian pada rapid miner dengan menggunakan algoritma Fp growth maka hasil pengolahan data pemesanan dan penjualan jajanan pasar yang dijual oleh dapoerin's adalah Lontong, putu ayu, piscok dan risol. 


\section{REFERENSI}

Firman, C. E. (2019). Penentuan Pola Yang Sering Muncul Untuk Penjualan Pupuk Menggunakan Algoritma Fp-Growth. I N F O $\begin{array}{lllllllll}R & M & a & T & I & K & A, & 9(2), & 1 .\end{array}$ https://doi.org/10.36723/juri.v9i2.97

Guide, B. P. (2018). Jajanan Pasar Tradisional, Murah dan tanpa bahan kimia. Retrieved July 31, 2021, from https://bpguide.id/AX1TCIdb

Kanti, S., \& Indrajit, R. E. (2017). Implementasi Data Mining Penjualan Handphone Oppo Store Sdc Tanggerang Dengan Algoritma Appriori. Implementasi Data Mining Penjualan Handphone Oppo Store Sdc Tanggerang Dengan Algoritma Appriori, (November), 1-2.

Kusbianto PA, D., Ananta, A., \& Nanda, B. (2019). IMPLEMENTASI ANALISA KERANJANG BELANJA GUNA MENENTUKAN PAKET PRODUK DENGAN ALGORITMA FPGROWTH, 1-5. Retrieved from http://jurnalti.polinema.ac.id/index.php/SIA $\mathrm{P} /$ article/view/624/220

Lestari, Y. D. (2017). Penerapan Data Mining Menggunakan Algoritma Fp-Tree Dan FpGrowth Pada Data Transaksi Penjualan Obat, (Snastikom), 60-65. https://doi.org/10.31227/osf.io/t93uv

Nurelasari, E. (2017). Penerapan Algoritma KMeans dan FP-Growth untuk Analisis Keranjang Pasar pada Penjualan Produk Alumunium, 1(2), 179-186.

Prasetyo, A., Musyaffa, N., \& Sastra, R. (2020). Implementasi Data Mining Untuk Analisis Data Penjualan Dengan Menggunakan Algoritma Apriori ( Studi Kasus Dapoerin ' S ), $\operatorname{VIII}(2)$.

Rahman, A. (2021). Pelaku Usaha Kuliner Keluhkan Dampak PPKM Darurat Jawa-Bali. Retrieved July 31, 2021, from https://lomboktvnews.com/pelaku-usahakuliner-keluhkan-dampak-ppkm-daruratjawa-bali/ 